\title{
PREVENTING SPECTATORS IN A GROUP-WORK: CIVIL TECHNOLOGY STUDENT'S PERSPECTIVE
}

\author{
Khojane Geoffrey Mokhothu \\ Department of Mathematics, Science and Technology, Central University of Technology Free State \\ (South Africa)
}

\begin{abstract}
Civil Technology is a subject which consists of content knowledge and practical work, of which one of the assessments requires group-work activity. Therefore, the problem encountered during group-work is that some of the students are concealing behind other claiming the vivid understanding of the work done. Group-work is one of the most imperative teaching and learning strategy which is underpinned by social constructivism, a theory that assumes that learning takes place through interacting with each other and through experiences. The aim of the study is to encourage common base understanding of content knowledge and practical work in a group-work learning, through problem-solving (Technological Process). However, the main objective was to evaluate the impact of group-work learning in Civil Technology content knowledge and practical work. While the main research question was, how does the positive impact of group-work learning assured in Civil Technology on content knowledge and practical work?

The research used a mixed method approach to collect data. The method of investigation included a literature review, empirical study by using the qualitative and quantitative method in the form of questionnaires and a semi-structured interview. The sample comprised of thirty-four (34) students both male and females from different cultural groups who are enrolled in Civil Technology III academic year. The findings of the study demonstrated that all group members in different groups successfully contributed and effusively participated in a group-work of Civil Technology teaching and learning.
\end{abstract}

Keywords: Group-work, civil technology, technological process.

\section{Introduction}

Group-work is one of the best teaching and learning strategy in Civil Technology as it promotes working together of students to attain a common social goal (Cohen and Lotan 2014:6). Doolittle and Camp (1999), state that experiential learning aligns with constructivism which posits that students construct meaning from their experiences learned from their peers. However, Civil Technology consists of different types of teaching and learning assessment techniques, which are aimed to prepare and evaluate them as the problem solvers (Mokhothu and Maimane 2017: 417).

While Khoza (2004) argue that lecturers who are teaching practical subject should determine the ways and the means to teach them as interesting subjects since they are practical.

\section{The conceptualisation of the study}

\subsection{Group-work}

Cohen and Lotan (2014:6) describe group-work as a structure where students working together in a small manageable group so that all group members can participate in a clearly assigned learning task. Amineh and Asl (2015:9) pronounce group-work as an element of social constructivism which is a theory of knowledge that examines the knowledge and understandings of the world that are developed jointly by individuals. 


\subsection{Civil technology}

Civil Technology focuses on concepts and principles in the built environment and on the technological process. It embraces practical skills and the application of scientific principles. This subject aims to create and improve the built environment to enhance the quality of life of the individual and society and to ensure the sustainable use of the natural environment (DoE 2014: 10: Mokhothu 2015:17).

The aim of the subject Civil Technology is to develop the skills levels of learners from Grade 10-12 to such an extent that they will be able to enter a career pathway at a Further Education and Training College or a university immediately after obtaining the National Senior Certificate. Learners will be ready to enter into Learnerships or apprenticeships that will prepare them for a trade test (DoE 2014: $11)$.

\subsection{Technological process}

Mokhothu (2015) highlights that the Technological process is the main assertive factor behind subject Civil Technology. As addresses the following "creativity, innovation and ingenuity play a major role in developing the students' full potential in this field" to integrate the theoretical work and practical's in three specialisations of the subject (Mokhothu 2015:34; Van der Walt 2009:26; DoE 2008:7). Six steps of the Technological process used in Civil Technology:

Step 1. Identify: Make a meaningful summary of the problem from the scenario given or created

Step 2. Investigation

- Design brief describes a problem, how do you think you can solve it and draw free-hand three possible solutions,

- Write specification and constraints.

Step 3. Design: Formal drawing plan with full details using the scale and material list

plan

Step 4. Make: Physically making your project using guided and corresponding with a formal

Step 5. Evaluation and Test: Compile a checklist for the project

Step 6. Communication: Presentation of the project (portfolio, project exhibition, and flow-chart

\section{The aim of the study}

The aim of the study is to encourage common base understanding of content knowledge and practical work in a group-work learning, through problem-solving (Technological Process).

\section{The objectives}

The main objective is to evaluate the impact of group-work learning in Civil Technology content knowledge and practical work.

\section{Proposition}

Group-work learning assures a positive impact in Civil Technology on content knowledge and practical work through the Technological process.

\section{Methodology}

\subsection{The context of the study}

The student attended formal classes of Civil Technology for theoretical content and practical work in the campus. The research conducted during the third term of their studies in Bachelor of Education SP and FET (BEd. SP\& FET) four-year program. A practical assessment task (PAT) was used to evaluate students' responses to the curriculum covered even in group-work.

\subsection{Participants}

All participants were Civil Technology third-year students enrolled at one of University of Technologies in South Africa. The total number of participants was 34, consisting of 19 males (56\%) and 15 females (44\%), which confirms $100 \%$ of participants. 


\subsection{Measures}

At the first stage all students were given a task to develop their own individual PAT applying all sixth step Technological process. and at the second stage participants were divided into four groups consist of 5 to 7 members to start their new PAT and each was presenting the work done from the first stage to group members, then working together with many of different ideas to develop one idea. Final stage the groups presented their complete PAT and other groups asked questions from the presentations.

\section{Results and discussion}

All the three tables below indicate the results from all the stages of assessment in the study.

Table 1. Individual assessment for PAT.

\begin{tabular}{|c|c|c|c|c|}
\hline Stage & Individual (N) & Frequency & Percentage (\%) & Average percentage \\
\hline \multirow{4}{*}{ Stage 1 } & \multirow{3}{*}{34} & 2 & 65 & \multirow{4}{*}{6} \\
\cline { 3 - 4 } & & 13 & 58 & \multirow{2}{*}{$66 \%$} \\
\cline { 3 - 4 } & & 1 & 51 & \\
\cline { 3 - 4 } & & 18 & 50 & \\
\cline { 3 - 4 } & & & \multicolumn{1}{|}{} \\
\hline
\end{tabular}

Table 2. Group assessment for PAT.

\begin{tabular}{|l|l|l|l|}
\hline Stage & Groups & Percentage & Average percentage \\
\hline \multirow{3}{*}{ Stage 2 } & 1 & 96 & \multirow{3}{*}{86} \\
\cline { 2 - 3 } & 2 & 89 & \\
\cline { 2 - 3 } & 3 & 79 & \\
\cline { 2 - 3 } & 4 & 79 & \\
\hline
\end{tabular}

Table 3. Group model presentation assessment.

\begin{tabular}{|l|l|l|l|}
\hline Stage & Groups & Percentage & Average percentage \\
\hline \multirow{3}{*}{ Stage 3} & 1 & 80 & \multirow{3}{*}{82} \\
\cline { 2 - 3 } & 2 & 85 & \\
\cline { 2 - 3 } & 3 & 73 & \\
\cline { 2 - 3 } & 4 & 90 & \\
\hline
\end{tabular}

The three tables above, shows the results of the study from stage 1 to 3 . Table 1 above reveals that student at stage 1 managed to achieve the average of $66 \%$. Which indicate that, all students in this study can work well individual in preparation to meet other students to up lift their knowledge. While at stage 2 the results show highest average of $86 \%$, which confirms that students can learn and express their excellence thinking, when they discuss and plan as a group. Table 3 indicate that student scored higher average of $82 \%$, at these stage students were showing and presenting their group practical work. All the above information concurs with Amineh and Asl (2015:9) early in the study, when they pronounce group-work as an element of social constructivism which is a theory of knowledge that examines the knowledge and understandings of the world that are developed jointly by individuals. Moreover, this research has proven that, in order for the student to achieve and solve the problem they need each other as all have the role to play. Therefore, no Spector's allowed in Civil Technology group work.

\section{Conclusion}

In conclusion, Civil Technology students are interested on group-work as it allows them to engage and gain more knowledge from others with confidence. Technological process promote creativity as students managed to design and do their own PAT. 


\section{References}

Amineh, RJ. \& Asl, HD. (2015). Review of constructivism and social constructivism. Journal of social science, literature and language, 1(1): 9-16

Department of Education. (2008). Learning Programme Guidelines Civil Technology. Pretoria: Department of Education.

DoE (Department of Education) (2014). Government Gazette, Vol. 589 No. 37840. Pretoria: Department of Education.

Doolittle, PE. (2014). Complex Constructivism: A Theoretical Model of Complexity and Cognition. International Journal of Teaching and Learning in Higher Education, 26(3): 485-498

Khoza SD (2004). Academic performance of engineering drawing N2 students of Ekurhuleni West College (ewc) in 2003. Magister Technologiae: Education. Pretoria: Tshwane University of Technology.

Mokhothu, K. \& Maimane, JR. (2017) Integration of civil technology theory content: students' practical work perspective, Education and New Developments $5^{\text {th }}$ Ed, 24-26 June, 2017. Lisbon, Portugal. ISBN: 978-989-99864-3-5

Mokhothu, KG. (2015). The Integration of Technical Subjects in Civil Technology Curriculum with Special Reference to FET Technical Schools. MEd Dissertation. Bloemfontein: Central University of Technology Free State.

Van der Walt, PN. (2007). Civil Technology for Grade10. 2nd Edition. Bloemfontein: Adonia Trust. 